\title{
Urban Land Grabbing Mayhem in Douala Metropolitan Local Council Areas, Cameroon
}

\author{
Tichafogwe Tende Renz \\ Department of Geography, Faculty of Arts, Letters and Social Sciences, University of Yaounde 1, Yaounde, Cameroon \\ Email: renztende@yahoo.com
}

How to cite this paper: Tende Renz, T. (2018). Urban Land Grabbing Mayhem in Douala Metropolitan Local Council Areas, Cameroon. Current Urban Studies, 6, 243259. https://doi.org/10.4236/cus.2018.62014

Received: April 8, 2018

Accepted: June 25, 2018

Published: June 28, 2018

Copyright $\odot 2018$ by author and Scientific Research Publishing Inc. This work is licensed under the Creative Commons Attribution International License (CC BY 4.0).

http://creativecommons.org/licenses/by/4.0/

\begin{abstract}
Anarchical land conquest in developing world cities is virally infecting Cameroonian cities epitome by its largest metropolis. This is what this paper sought to portray of the successive augmentation of the Douala V Local Council urban space distinct by a weird anarchy-driven population growth. It posits that it is not just available unoccupied space but institutional indolence has of recent hemmed in urban infrastructural disorder that has led slums grow beyond bounds. Multi-temporal Landsat images for 1975 and 2015 and a Spot image of 1995 were used to determine the spatial colonization and expansion land use/land cover analyses. Results were corroborated with field information through field surveys using structured questionnaires. Findings permitted us note that space colonisation in Douala $\mathrm{V}$ experienced a 60.18\% upward trend of built-up areas just in four decades (1975-2015), with a $1.5 \%$ annual population growth rate. Implications on the urbanscape have been an accelerated and severely degraded forest and natural vegetation form the 1403\% growth urban human surge in 42 years (from 57,000 1975 to 800,000 inhabitants in 2017). Douala V thus emerged as an "try and see" land colonisation territory where new arrival of inhabitants inadvertently sowed structural anarchy valued at $51 \%$ permanent and $49 \%$ temporary structures. Noting that such disorder emanates from top-down urban governance and management this study recommends that urban planning legislation concerning must be inclusive of grass roots to guarantee involment as a canon of sustainable development in modern and post-modern times.
\end{abstract}

\section{Keywords}

Anarchy, Colonisation, Institutional Responses, Population Growth, Urban Space

\section{Introduction}

Anarchical settlement and colonisation of space is characteristic of some parts of 
Cameroon, with the case of Douala being very preoccupying. Uncoordinated expansion has affected the development of the Douala urban area as the continuous occupancy of space in the midst of increasing economic hardship has resulted in an uncontrollable spatial layout of urban settlements. The urban planning policy of Cameroon and the execution lapses in Douala have led to wide spread anarchy in the city, especially in the Douala V municipality. Most towns in Cameroon suffer from serious urban planning problems due either to the lack, or non-implementation, of urban planning norms (Priso Olivier, 2014). These difficulties are recurrent in the expansion process of the towns.

Space colonisation by settlement area remains an unescapable process in urbanization. The consumption of space, nevertheless, leaves much to be desired as its occupation at a given point in time is done in a disorderly manner. The population remains the principal actor behind this disorder as the forest reduces due to the continuous advancement of man (Priso Dickens, 2016). This, in other words, reveals that the human pressure on the available space from population growth is on a perpetual rise, thereby encroaching into and reducing vegetation. Since urbanisation and industrialization have accelerated the growth in the population that moves into Douala in search of employment and better standards of living, those who can not afford decent housing are left with no choice than to settle for the squatters and slums (Ngoran \& Xue, 2015).

The process of urban sprawl in Cameroon in general and that of Douala in particular does not only occur in an uncoordinated manner, but is also unplanned despite prohibitions by the State. The general trend of space colonisation in Douala is outwards from the city centres of Akwa, Bonanjo, Bali as well as Deido towards the peripheries of the north, west, east and south directions of the town (Mbaha \& Ndock, 2013). Settlement space in the city centre has become saturated. As a result, the population is now rushing into the suburbs. This mass movement to the peripheries has brought about the invasion and occupation of space in the Douala V municipality.

Located in the inter-tropical zone in the Gulf of Guinea in the Wouri estuary between latitude $4^{\circ} 3^{\prime}$ and $4^{\circ} 7^{\prime}$ North and longitude $9^{\circ} 42^{\prime}$ and $9^{\circ} 48^{\prime}$ East, Douala $\mathrm{V}$ has a tropical humid climate. The annual rainfall is more than $4000 \mathrm{~mm}$ with temperatures ranging between $24^{\circ} \mathrm{C}$ and $27^{\circ} \mathrm{C}$ hence, characterised by wet and dry seasons. Created by Decree No. 093-321 of $25^{\text {th }}$ November 1993, Douala V has an estimated surface area of 21,000 hectares with a population density of 145 persons $/ \mathrm{km}^{2}$. It is the second largest Municipality after Douala III, bounded by the Nsape Drainage Basin to the North, Douala II and the Wouri River to the West and Douala III to the East and South (Figure 1).

The total population of this municipality stood at 538,449 inhabitants (BUCREP, 2005). The Douala V Local Council has a youthful population with the youths making-up about $70 \%$ of the total population. The successive growth in the urban space of the Douala V local council is compounded by anarchy from rapid population growth. The objective of this article is to map-out the 


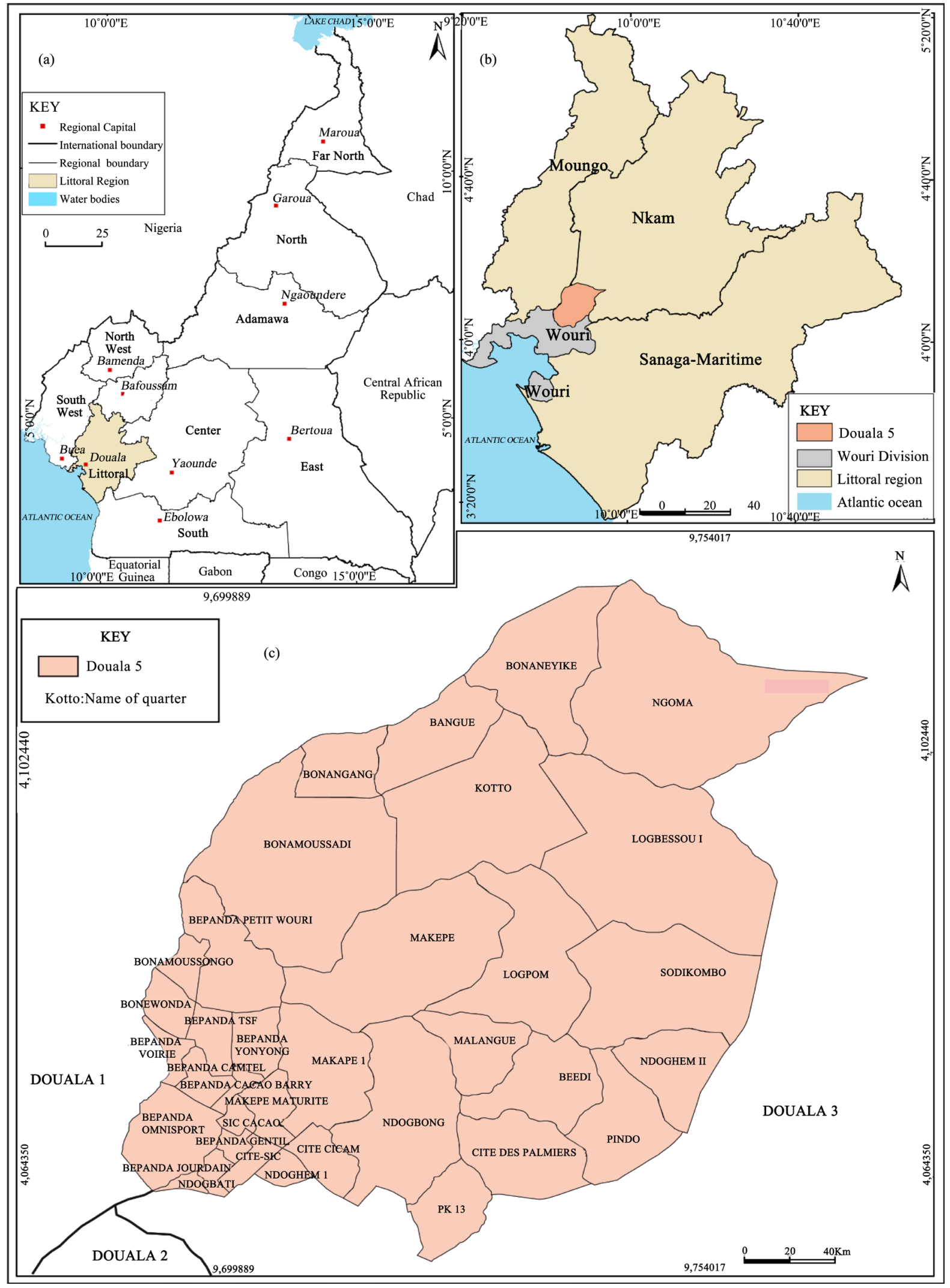

Figure 1. Location of the Douala V Municipality. (a) Littoral recion in cameroon; (b) Wouri division in the littoral region; (c) Douala 5 sub-division. Source: Modified from DUC by Tende, 2018. 
progressive occupation of space in the Douala $\mathrm{V}$ municipality and direction of occupancy. The paper illustrates how unplanned space occupation has provoked urban anarchy in the area and how curbing strategies can be introduced.

\section{Methodology}

In order to determine the land use/land cover change to reveal space colonisation and progression in the Douala V municipality, satellite images were used. Two periods of Landsat images were used to determine the land use/land cover of 1975 (Landsat MSS) and 2015 (Landsat OLI8). An additional spot image of 1995 was used to analyse land use/land cover of the area. The treatment was done in three phases: the pre-treatment phase which was done to correct the atmospheric implications on the different periods of the images, which were later regrouped to form an image of several bands to confirm the geo-referencing. The classification and post-classification phase followed before the images were validated. These images were treated with the use of the ArcGIS software. Data from the treated images were used to generate tables, to analyse and determine the rate of urban space colonisation and progression in Douala V.

Data collected through field survey from questionnaires and interviews were treated and interpreted through the Microsoft Excel spreadsheet so as to generate tables and diagrams for analyses. Interviews were used to gather data that could not be gathered by way of direct observation and or questionnaires. Using the household as a unit of observation, the questionnaire were administered to the respondents of the various quarters of the Douala V municipality at home and in their business places not far from home, depending on their preferences. A $0.5 \%$ household sample (122,188 households) of the 538,449 inhabitants of the Douala V municipality (BUCREP, 2005) was done. This was done by dividing the total number of households by 100 , and multiplying it by 0.5 , to arrive at 610.94 intended respondents $(122,188 / 100) \times(0.5)=(610.94)$. However, some 565 effective responses were gotten from the administration of questionnaires which were then used to determine the causes and manifestations of urban anarchy in Douala V. Field research was both qualitative and quantitative, and were analysed to generate results.

\section{Results and Discussion}

Findings propound that space colonisation and urban anarchy in the Douala $\mathrm{V}$ local council are triggered by the availability of unoccupied space and population growth which have caused spontaneous and unplanned development.

\subsection{The Douala V Space Occupation and Progression Trend}

Space occupation through the invasion and colonisation of the land by the built-up area has increased overtime in the Douala V local council. The encroachment was triggered by rapid population growth and urban sprawl leading to an increase in the built-up space. The rate of progression in the Douala $\mathrm{V}$ 
municipality shows that the built-up area has increased by $60.18 \%$ for the past forty years (1975 to 2015). The built-up annual encroachment rate by the area is $1.50 \%$, considered to be rapid. This rapid rate of increase is as a result of high population movement into Douala $\mathrm{V}$ from neighbouring areas due to availability of cheap and unoccupied space, as well as low government control. The Douala $\mathrm{V}$ local council is therefore in-filled with a cosmopolitan population that has colonised the space and is rapidly changing (Table 1 ). The unoccupied urban space has regressed by $-20.44 \%$ in forty years at an annual rate of $-0.51 \%$. The regression of the unoccupied urban space is due to the colonisation of the space by the built-up area. The degraded forest has also regressed by a minus $23.98 \%$ in the past four decades, reducing at $-0.59 \%$ annually (Table 1 ).

The natural forest as well has regressed by $-44.54 \%$ in forty years at an annual rate of $-1.11 \%$. The regression of the unoccupied urban space, degraded forest and natural vegetation is a clear indication of the rapid extension of the Douala $\mathrm{V}$ municipality urban spaces.

The occupation of space at post-independence in Douala V was unidirectional and concentrated in the south western part of the area. By 1975, the urban space encroached into the vegetation, thereby, transforming the land into a settlement zone. The 1975 Landsat Image revealed that only 810 hectares of land were occupied by built-up at the time. The built-up was mostly concentrated in the Bepanda, Cite CICAM, Ndogbong, Cite SIC and Ndogbati neighbourhoods, which were identified as the sprawl areas at that time. The degraded forest in 1975 was 2073 hectares and that of the natural forest was 2933 hectares. The degraded forest was invaded by farming and other agricultural activities, indicating that the area had less built-up and more farmland. Such characteristics reveal that by 1975 , Douala V was more rural than urban. The built-up area covered $14 \%$ of the total surface while farmland in the area covered $36 \%$ of degraded forest.

Table 1. Evolution of urbanscape typologies in Douala V 1975 to 2015 (in hectares).

\begin{tabular}{|c|c|c|c|c|c|c|c|c|}
\hline \multirow{3}{*}{$\begin{array}{c}\text { Type } \\
\text { Built-up Area }\end{array}$} & \multicolumn{6}{|c|}{ Period } & \multicolumn{2}{|c|}{ Rate of progression } \\
\hline & \multicolumn{2}{|c|}{1975} & \multicolumn{2}{|c|}{1995} & \multicolumn{2}{|c|}{2015} & \multirow{2}{*}{$\begin{array}{c}40 \text { years } \\
60.18\end{array}$} & \multirow{2}{*}{$\begin{array}{c}\begin{array}{c}\text { Annual } \\
\text { progression }\end{array} \\
1.50\end{array}$} \\
\hline & 810 & 13.93 & 2218 & 38.14 & 4310 & 74.11 & & \\
\hline $\begin{array}{l}\text { Unoccupied } \\
\text { Urban Space }\end{array}$ & - & - & 1674 & 28.78 & 485 & 8.34 & -20.44 & -0.51 \\
\hline Natural Forest & 2933 & 50.43 & 1001 & 17.21 & 343 & 5.89 & -23.98 & -0.59 \\
\hline $\begin{array}{l}\text { Degraded } \\
\text { Forest }\end{array}$ & 2073 & 35.64 & 923 & 15.87 & 678 & 11.66 & -44.54 & -1.11 \\
\hline Total & 5816 & 100 & 5816 & 100 & 5816 & 100 & & \\
\hline
\end{tabular}

Source: 1975 Landsat, 1995 Spot, 2015 Landsat Satellite images and field work, 2017. 
The unidirectional and continuous wave of the sprawl pattern was concentrated in some six to seven neighbourhoods of Douala V. The sprawl pattern of the Douala V municipality in 1995 became polydirectional and had increased in scope contrary to that of 1975 . The sprawl tongues no longer concentrated only in the south western part of the area, but extended to the south east and parts of the central zone. An examination of the 1995 Spot Image revealed an increase in the built-up area from 810 hectares in 1975 to 2218 hectares in 1995 . Unlike in 1975 where the natural vegetation and degraded forest occupied more space than the built-up area, the reverse was produced twenty years later in 1995. The degraded forest reduced in area from 2073 hectares in 1975 to 923 in 1995. The natural forest covered 2933 in 1975 was only 1009 in 1995. An unoccupied urban space emerged and was covered by farmland, enabling an increase in the agricultural activity space from 00 to 1678 hectares of land in 1995. These changes provoked the sprawl to neighbourhoods such as Beedi, Malangue and Ndoghem towards the south east of the front; to Makepe, Bonamoussadi and Bonangang towards the North West and central zone of the municipality. By 2015, the sprawl pattern in the Douala $\mathrm{V}$ municipality took significant poly-directional proportions. The sprawl spread into three directions of the south, west and east sections of the municipality, with a slow movement towards the north. The Landsat Image of 2015 revealed an increase in the built-up area from 2218 hectares in 1995 to 4310 in 2015 . This represents an increase of $35.97 \%$ in twenty years. This indicates significant increases in the built-up area, representing $1.50 \%$ annual average increase. The built-up area increased by 2092 hectares, that is, from 2218 in 1995 to 4310 in 2015 (Figure 2).

These changes affected the space and sprawl pattern as they provoked the spread into four directions of the municipality, thus creating new neighbourhoods such as Makepe Missoke, Sodikombo, Kotto, Bangue, Logpom, Logbessou, as well as Ngoma. The built-up area of the Douala V local council in 2015 covered $74.11 \%$ of the total surface area. The creation and consumption of urban space in Douala $\mathrm{V}$ has progressively increased overtime. It is worth nothing that this progressive colonisation of space has been instigated by the human growth weight of the municipality.

\subsection{Human Growth Weight and Incidence on Urban Anarchy in the Douala V Local Council}

Just like the urban space, the human growth weight in the Douala V local council, is constantly increasing over time. Changes in population are on a steady increase from 1975 to 2017. The Douala V municipality, with its significant population of $28 \%$ of the total population of Douala, is predominantly poor. It has a population growth rate of $7.5 \%$ (CUD, 2015) which is also highly diversified in its ethnic composition. The growth was triggered by the creation of the Douala Autonomous Sea Port which pulled a large number of people into the city and eventually to the municipality for settlement. Added to the possibility of gaining 


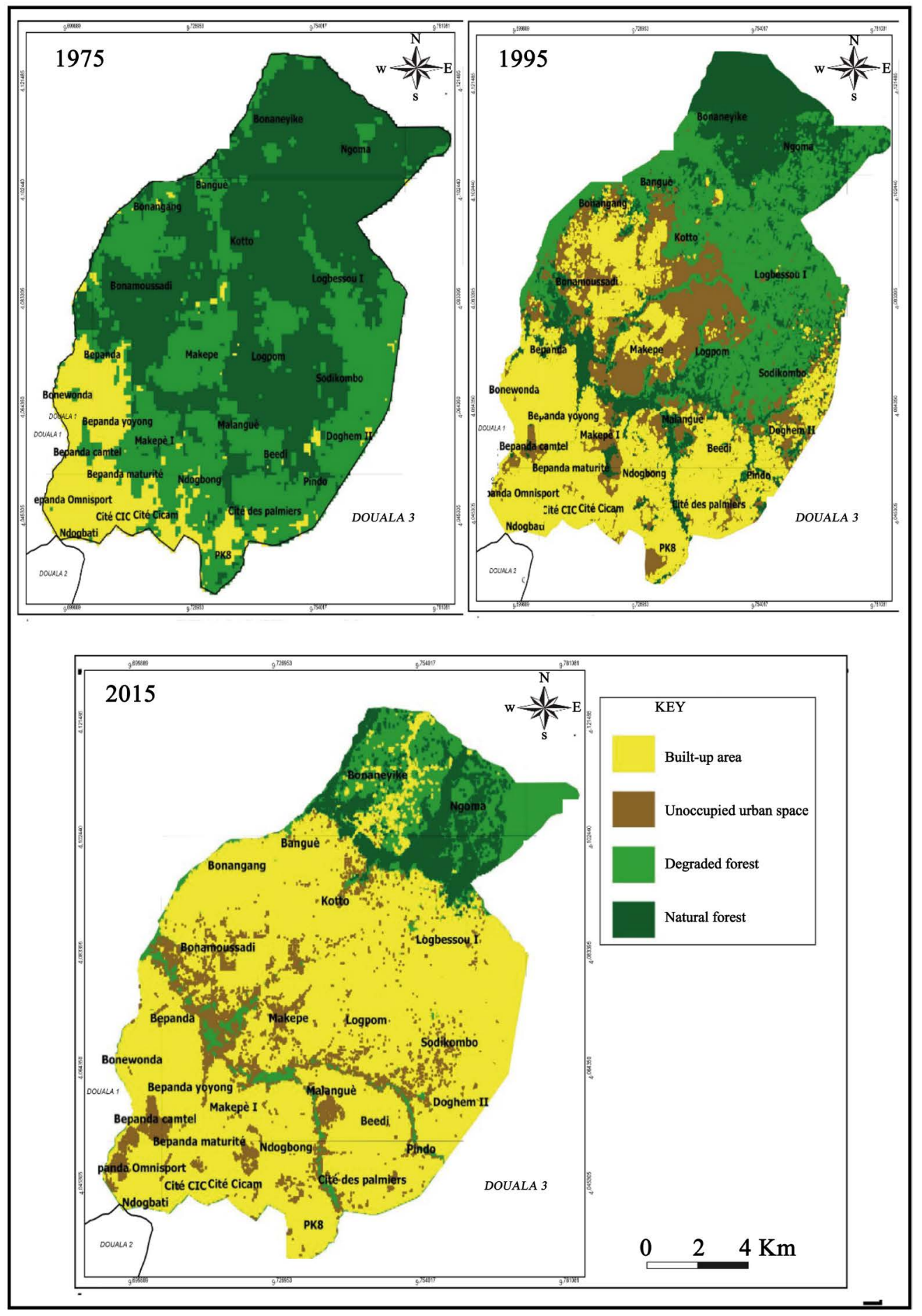

Figure 2. The Douala V local council space progression from 1975 to 2015. Source: 1975 Landsat, 1995 Spot, 2015 Landsat Satellite images.

employment, was the availability of unoccupied and uncontrolled but cheap space which made for an easy access to land for settlement by the in-migrants (Nsegbe, 2012). As a result of this, many migrants who moved into Douala rushed there because of the available space in the municipality, thereby causing 
the population of the area to experience constant growth. The population of Douala $\mathrm{V}$ has experienced changes for the past 40 years. Within the period from 1987 to 1997, the marginal increase was at 205,097 people even though they was a general drop in the population of the entire city of Douala. This was due to the economic crisis of 1987 which reduce the number of people who moved into the city of Douala (Table 2).

The period from 1997 to 2005 also experienced a decrease from 165,203 to 162,449 people. Unlike the marginal increase in the population of Douala V which was high in 1987 and low in 1997 and 2005 with a projected increase in 2017, that of the percentage increase dropped and was only projected to increase in 2017. The drop in the percentage increase in the population from 1987 to 2005 is explained by the fact that after the economic crisis, the population of Douala experienced a slow growth rate. The few people who could withstand the difficulties of the economic crisis colonised the cheap and available land and settled for low class housing. With the economic growth of the country after her debt cancellation in Cameroon in 2008, the population began to increase and by 2017, the percentage increase in the Douala V local council rose to $32.69 \%$.

Natural increase is not the only factor that has caused the growth of the population; in-migration is also another cause. Out of the $56.70 \%$ in-migration rate into the city of Douala, 20\% moved to and settled in Douala V (BUCREP, 2005), ranking as the first migrant recipients amongst the six municipalities of the city. According to the 2005 population and housing census, Douala had a population of $1,931,977$ inhabitants with 538,449 of them found in the Douala V local council, representing $27.87 \%$ of the total population $(1,931,977)$. This is responsible for the high population density in the area, which has led to the creation of squatters and slums, resulting in urban anarchy. The Douala V municipality is made up of a cosmopolitan population that is involved in various trades ranging from traders, farmers, administrators, to civil servants, accountants, medical doctors as well as military officers. Contrary to the population of other parts of Douala which is made up of the Doualas and the Bassa, that of Douala V harbours mainly the Bamileke ethnic group (Meva'a Abomo \& Fogwe, 2015). This ethnic dominance led to the development of low quality infrastructure which is an indication of anarchy in the area. The migration trend in Douala V like that of the city as a whole has evolved overtime (Table 3).

The rate of migration into the Douala $\mathrm{V}$ municipality has been increasing for the past 40 years. Of the 52\% migrants into Douala in 1987, 14\% settled in Douala $\mathrm{V}$ and the rest (38\%) settled in the remaining five municipalities, indicating that the impact is greatest on Douala V. The rate of migration into Douala $\mathrm{V}$ was $27 \%$ of the total $62.20 \%$ for the city. This reveals that more migrants moved into the area than to other municipalities.

\subsection{Urban Anarchy and Institutional Responses in the Douala V Local Council}

Urban anarchy in the Douala V municipality has influenced settlement. The 
Table 2. The evolution of the population of Douala V from 1976 to 2017.

\begin{tabular}{cccc}
\hline Year & Population & Marginal increase & Percentage increase \\
\hline 1976 & 57,000 & - & - \\
1987 & 210,797 & 205,097 & 97.29 \\
1997 & 376,000 & 165,203 & 43.93 \\
2005 & 538,449 & 162,449 & 30.16 \\
2017 & 800,000 & 261,551 & 32.69 \\
\hline
\end{tabular}

Source: BUCREP, 1976, 1987, 2005, 2010 Projections and CUD projections 2017.

Table 3. Evolution in migration rate and marginal increase in Douala V.

\begin{tabular}{ccc}
\hline Year & Migration Growth Rate (\%) & Marginal Increase/(\%) \\
\hline 1976 & - & - \\
1987 & 14 & - \\
2005 & 20 & 6 \\
2015 & 27 & 7 \\
\hline
\end{tabular}

Source: BUCREP, 1976, 1987, 2005, 2010 Projections and CUD, 2015.

pattern is more or less a non-organised or unplanned built-up surface rather than an organised or a planned one. The organised built-up constitutes $13.9 \%$ of the total urban surface, while the non-organised constitutes 56.1\% (CUD, 2015). This is an indication that a greater part of the area is unplanned. This disorganised planning results from the non-respect of instituted urban laws by most urban inhabitants in the area. The violation of town planning laws, therefore, has affected the urban settlement pattern of the area, thereby changing its morphology. Urbanisation terms of reference in Cameroon require that planning comes first before settlement. The contrary is observed in the Douala V municipality wherein the population settles before planning, thereby causing disorder in land occupation in the area. The inhabitants move into the area and settle without any respect of the law and little is done by the authorities to prohibit this type of settlement. The initial settlers on prohibited areas were to be ejected by the authorities. Rather, the authorities were laxed and even became accomplices in the sales of plots. The population settled in a "try and see approach", expecting a reaction from the government which never came.

The general town planning and building rules of Cameroon clearly prohibit urban anarchy. Section 9 of Law No. 2004/003 of $21^{\text {st }}$ April 2004, on rules of urban anarchy, stipulates that:

- Except otherwise or especially prescribed, any land in danger of a natural hazard such as flood, erosion, landslide and earthquake, portions of State land classified as such, as well as ecologically protected areas as defined by legislation relating to environmental management shall not be built on.

- Any land in danger of an industrial hazard or serious nuisances (industrial 
and noise pollution) and land likely to jeopardise public health or local cultural values shall not serve as a unit for habitation.

- Zones where such lands are located shall be defined by town planning documents or, failing that, by municipal order.

- Protected measures and the safety distances to be considered in drafting town planning documents shall be defined by the competent government services, particularly those in charge of mines, defence, the environment, tourism and lands (Law No. 2004/003 of 21st April 2004).

Considering the various prohibitions by the law, such anarchy would have been completely eliminated in urban spaces in Cameroon.

The anarchy that reigns in the Douala $\mathrm{V}$ municipality in terms of urban space occupation has influenced land ownership and the quality of infrastructure in the area. The irregularities observed in the acquisition of, and building on, land came from the fact that builders do not follow any organised format, leaving behind varied shapes and types of sub-standard buildings. A majority of the inhabitants of Douala $\mathrm{V}$ do not legally own the land they have constructed on. Of some 565 households in the area, 160 owned land titles, 230 were without land titles, and 175 were the households of tenants who remained indifferent in their responses. This represents $28.3 \%$ of the inhabitants owning land titles and $40.7 \%$ without land titles. The results clearly indicate that a majority of the population that resides in the Douala V local council are illegal residents. Thus, this promotes anarchy in the area.

Several reasons account for the increasing number of households without land titles. The $40.7 \%$ of households sampled explained that the titling procedure is long and cumbersome, compelling the people to acquire land illegally. Obtaining a land title for a piece of land involves three Ministerial Departments (MINATD, MINDUH and MINDCAF) ${ }^{1}$ as well as the Douala Urban Council and Local council. This lengthens the time frame involved in the acquisition process and discourages those who are willing to obtain a land title. The procedure is not only long, but is also very expensive, amounting to hundreds of thousands of Francs CFA. Such costs are heavy to an average inhabitant and deter them from using their savings reserved for construction for the purpose of obtaining a land title. As a result, they settle without any land title leading to anarchy.

Associated to the high costs are other illegal costs in the form of tips perpetuated by middlemen who claim to be able to facilitate the process for the inhabitants and end up extorting money from them. These difficulties have pushed a good number of the inhabitants to violate building laws and build house without land titles. The long and cumbersome procedure involved in land ownership and the irregularities entailed in obtaining a building permit has led to the poor quality of infrastructure in Douala V.

Two classes of infrastructure can be observed in the area which are the ${ }^{1}$ MINATD: Ministry of territorial administration and decentralisation. MINDUH: Ministry of Housing and Urban Development. MINDCAF: Ministry of surveys, state property and land tenure. 
sub-standard or make-shift and the standard or modern buildings. Sub-standard housing is that which deteriorates faster due to the fact that they are built out of locally made materials, harboured by squatters and slums (Priso Olivier, 2014). Such housing is typical of the New Bell quarter in Douala, characterised by overcrowding and a decomposition of the structures. It is mostly owned by the urban poor who can not afford decent housing in the city, owing to their social status and income level. The urban poor, therefore, settle illegally in violation of urban laws. The non-respect of urban laws and anarchy have made some of the inhabitants of Douala V having no land titles and building permits to build temporary houses made out of locally fabricated material, sticks and mud. The few who own land titles and building permits live in permanent houses made out of modern materials of cement bricks and other standard items. Of the 565 houses sampled in the area, majority of the temporary houses found in the area belong to inhabitants who have no land titles and building permits. Most of the houses as well are found in zones forbidden for settlement. As a result of the anarchy and for fear of demolition, inhabitants begin with the construction of temporary houses before transforming them into permanent ones later.

Anarchy in space occupation in the Doula V municipality has prompted the State and Council authorities to institute governance policies to counter the difficulties in place. The State, the Council and other institutions have decided to react to the disorder in the area. Their actions started with a general evaluation and identification of forbidden infrastructure. The sign post on Plate 1 carries information in French which when translated, reads thus: "construction is forbidden in this risk zone." This information legally prohibits any space colonisation and settlement in such risk-prone zones. It allows the authorities to apply sanctions as in Chapter 1, Section 2 of the 2008 Law of Urbanisation in Cameroon. Such information is not supposed to be violated by any inhabitant of Douala. Nevertheless, this is not the case as the areas have been occupied by the population (Plate 1).

Plate 1 shows the Makepe Missoke and Bepanda Voirie neighbourhoods with a sign post from the Douala Urban Council forbidding any form of construction and settlement. Nevertheless, settlement can still be identified in these neighbourhoods despite the injunctions. Interviews conducted with the authorities of the

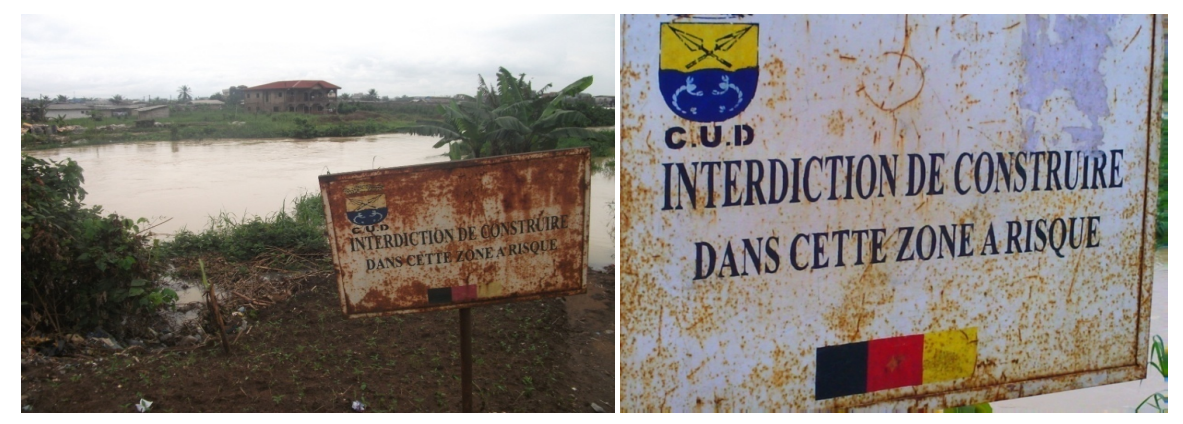

Plate 1. Prohibition signs to settlement in Douala V. Tende, October 2017. 
Douala V Council and field work carried out revealed that the Makepe Missoke, Bepanda Voirie, Cacao-Berry-Ndogbong valley, Beedi valley, Cite de Palmiers valley and Malangue valley were neighbourhoods strictly forbidden for human settlement. The halt of buildings and settlement in these neighbourhoods of Douala $\mathrm{V}$ did not deter the population from invading the quarters. Unfortunately, the authorities did not stop and demolish the early inhabitants from the prohibited zones such as Makepe Missoke in 1985 and Bepanda Voirie in 1980 (Figure 3).

Consequently, other people came and the neighbourhoods became totally occupied. Since the anarchy persisted, the authorities proceeded by other means such as the earmarking of houses for demolition as a move to redress the situation in Douala V (Plate 2).

Plate 2 shows buildings identified for demolition in the Makepe Missoke neighbourhood of the Douala $\mathrm{V}$ municipality. The buildings carry the sign (AXD) which signifies "à démolir", meaning "to be demolished", serving as an injunction stipulating destruction. It is marked on a business or residential structure by the authorities of the DUC or the Douala V Council. The sign is placed on buildings that do not conform to the legal norms required by planning laws regarding authorisation to build on prohibited sites or on legalized construction using unacceptable material. Before the sign is placed on a building, the owner receives a written document from the DUC or local council authorities that explains the violation of the law. This owner is granted a period of 90 days for re-adjustments or evacuation. Immediately after the three month period elapses without any reaction from the defaulter, the council authorities then proceed with the marking of the structures for demolition. After earmarking a house for demolition, a period of 72 hours is granted for the occupants to evacuate the area prior to the demolition as stipulated by law.

The authorities concerned at this point have carried out the stipulated legal procedures and have identified those buildings which do not conform to the urbanisation norms of reference and granted injunctions for the owners of the buildings to evacuate the place. These signs can be seen in almost all the neighbourhoods of the area, especially in those areas where settlement is prohibited. Due to the sluggishness of the authorities of the DUC and Douala V Council to carry out the demolition, populations hastily complete the buildings already marked for demolition and occupy them. The space colonisers and inhabitants of the Douala V local council have therefore developed demolition avoidance strategies in the course of time in order to resist State action (Table 4).

The five demolition avoidance strategies in the table above have been used by the people building in Douala V have influenced the rate of urban disorder. The rapid completion of identified buildings for demolition is ranked first. The owners of the buildings marked are aware that they are acting in violation of the law and adopt the rapid execution strategy as the only way to by-pass State control 
measures and own a house. Other space colonisers decide to clean-up the sign on their buildings and continue the work on them in total disregard of the law. Others fence their compounds during the building process so as to conceal them

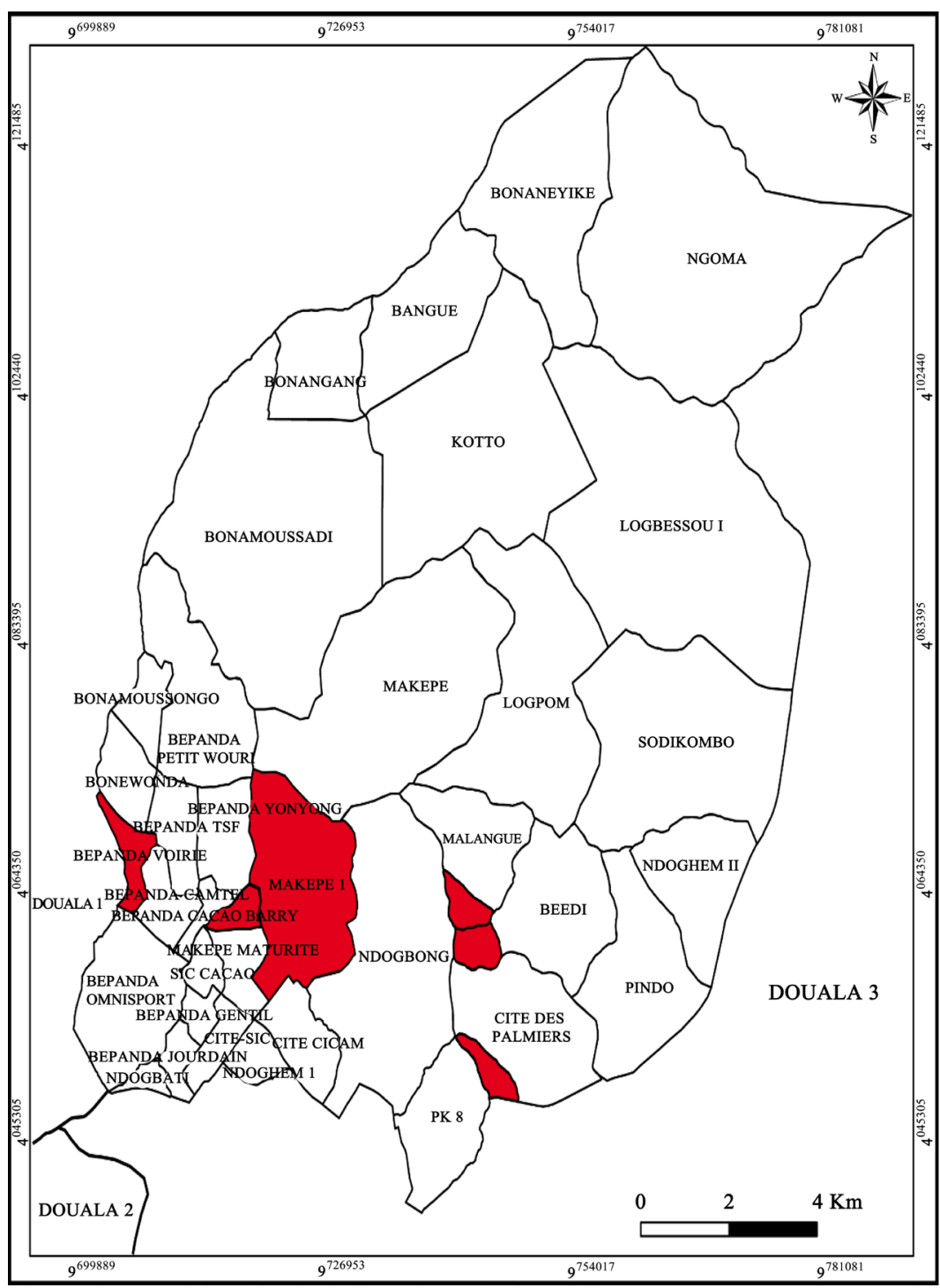

Figure 3. Prohibited zones for settlement in the North East front of Douala. Source: Field Work, 2017.
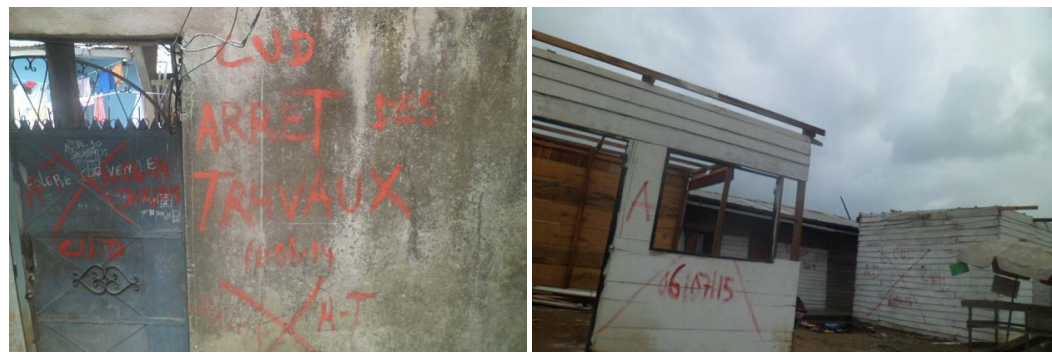

Plate 2. Buildings earmarked for demolition in Douala V local council. Tende, October 2017. 
Table 4. The classification of demolition avoidance strategies by inhabitants of Douala V.

\begin{tabular}{cr}
\hline Classification ranking & Demolition avoidance strategies \\
\hline 1 & Rapid completion of identified building for demolition \\
2 & Fencing of compound during construction to prevent checks \\
3 & Corrupting Council officials during spot checks \\
5 & Re-construction of buildings on another piece of land \\
\hline
\end{tabular}

Source: Field work, 2017.

from authorities and thus avoid any intrusion and interruption. Some other people corrupt Council officials during routine checks structures through bribery. These corrupted officials, having collected money, then find it difficult to order the construction to come to a halt and thus contribute in perpetrating anarchy. Some other people have decided to change their building locations and more away from the already marked ones. These demolition avoidance strategies have increased the rate of urban anarchy in Douala V as space colonisation has encroached even more into forbidden zones.

The disorganisation resulting in anarchy that is reigning in the city has led to unplanned development in Douala V. The authorities of the area do not act fast enough thus, in the course of the delay, most defaulters hastily complete their buildings while disregarding State laws and team up with other inhabitants to pose a social problem such as rioting, in case of any destruction and relocation. Governance and institutional responses to anarchy in Douala V have met with stiff resistance from the population. This has led to an irrational management of the urban land use in the area (Tchounga, 2015). It has also given room for anarchy which has distorted the entire morphology of the urban space.

\section{Conclusion}

Space colonisation and settlement in the Douala V local council is unplanned and compounded by anarchy. This is due to the availability of unoccupied space and population growth which has led to the settlement of people with no respect for town planning norms. Settlement has therefore preceded planning, leading to unplanned development. Despite some State interventions, anarchy can still be identified in the Douala V local council and remains a problem to its development. It is in the light of the foregoing analyses that this paper suggests that the State, local council and civil society work in synergy to address anarchy in the Douala V local council in particular and the entire city in general. In this way, decisions concerning the population will take into account grassroots participation and will salvage the already drowning Douala V local council from urban disorder. Some possible suggestions to curb anarchy at best in the Douala $\mathrm{V}$ local council and other urban spaces are proposed in the policy implication.

Space colonisation and urban anarchy in the Douala V local council have led 
to more unplanned than planned development which could be addressed through a participatory management approach. The management of the Douala $\mathrm{V}$ municipality, through the decentralisation law in Cameroon is now the responsibility of local council authorities. The governance of the urban land use of the area is not only the responsibility of the authorities of the council alone, but also that of others, such as the civil society and private actors. Therefore, the management of anarchy in Douala V should not only be left to the State but should follow a complementary participatory action from all stakeholders involved in the growth of the town.

\section{Some Possible Solutions to Curb Urban Mayhem in the Douala V Local Council}

The State is very involved in the management of urban anarchy either through its institutional or other decentralised organs. She plays the role of regulator and indicator of public policies and fights against anarchy through the financing of projects geared towards the development of the local council through the "Fonds spéciales d'équipement et d'intervention intercommunale" (FEICOM). The Douala Urban Council and the Douala V Local council are supposed to work together to ensure proper land use planning and zoning to ameliorate the intriguing situation.

The population is another significant actor in the governance of the urban anarchy in Douala V as it constitutes the main non-State actor that is supposed to be included in urban space management to curb anarchy in the municipality. Unfortunately, the decisions that affect their management are most often taken without any consultation of the population or the association of those concerned. It is advisable to adopt a participatory governance approach by involving the population in the decision making exercise. Instead of using force, it is preferable to institute a spirit of dialogue since the population concerned is striving for a better standard of living. This is because the participation of ordinary people in decisions that affect their lives would be a better way of solving the problem of anarchy. Legislation concerning urban planning and management should, therefore, make room for grass roots participation. The State legislature should ensure that the aspect of institutionalisation of local government through grass roots participation is enshrined in urban planning laws. What is required, therefore, is the improvement of competence at the level of the local authority. The strategies for this type of reformation include capacity building, institutional development and the encouragement of local participation. The more localized the urban laws, the greater the chances of their effectiveness with respect to solving problems of anarchy.

Furthermore, the Civil Society and the Non-Governmental Organisations (NGOs) are other non-State actors that have a role to play in the growth and governance of the Douala V municipality. These organs which include the United Nations Development Programme (UNDP), UN-Habitat, as well as the 
World Bank, contribute in one way or the other through financial aid to foster the growth of the local councils through the execution of projects in Douala. Such organs may serve as observers and advisers to the authorities on which sustainable management strategies to use in governance which should not be taken lightly. Other measures such as the role of the media in the education of the population will significantly contribute in the transmission of information in both the public and private mediums. It is in the best interest of all that the three main actors (State, population and civil society) work in synergy to curtail the high degree of urban anarchy which has distorted the urban land use of the Douala V municipality. The governance of anarchy in the area should take cognisance of the culture and tradition of the people. It is important to note that one unit of governmental power alone cannot preside over the power of decision making in urban planning, as policy making certainly does not belong entirely to the State. This is because the problems involved in planning have a more local character which the State alone cannot take charge of single-handedly. The State and the population are expected to cooperate so as to control the intensity of anarchy which has affected the sustained growth of the Douala V local council.

It is interesting to note that, curbing anarchy in the Douala $\mathrm{V}$ local council seems to be a herculean task since settlement has preceded planning. Decision makers are finding it difficult to redress the situation because the inhabitants have teamed up to raise a social problem of inadequate means to relocate. The authorities can therefore only succeed to curb anarchy at best if the State decides to sponsor the relocation.

\section{References}

BUCREP (2005). National Population and Housing Census of Cameroon of 1976, 1987, 2005, and 2010 Projections. 567 p.

CUD (2015). Plan Directeur d'Urbanisme de Douala à l'horizon 2025. 240 p.

Law No. 2004/003 of $21^{\text {st }}$ April 2004. To Regulate Town Planning in Cameroon. 467 p.

Mbaha, J. P., \& Ndock, G. (2013). Cinquante ans de conquête spatiale à Douala: d'héritage colonial en construction à patrimoine socio-spatial vulnérable aux risques naturels. In Colloque du Cinquantenaire de la République du Cameroun (pp. 415-435). Actes du Colloque Douala, 13-14 Février 2013.

Meva'a Abomo, D., \& Fogwe, Z. N. (2015). Peut-on prétendre à l'émergence urbaine a l'horizon du centenaire (2060)? In Urbanisation et Développement humain au Cameroun (pp. 23-28). Collection Etude et Recherche Action pour le Développement de l'Afrique, des Caraïbes et du Pacifique (CERAD-ACP), Société Savante Cheikh AntaDiop (SS-CAD), Volume 1, Editions Universitaires Européennes.

Ngoran, S. D., \& Xue, X. (2015). Addressing Urban Sprawl in Douala, Cameroon. Lessons from Xiamen Integrated Coastal Management. Journal of Urban Management.

Nsegbe, A. (2012). Analyse géographiques des pressions environnementales résultant de L'urbanisation du littoral Camerounaise: Cas de Douala et Kribi. Thèse de Doctorat, L'Université de Yaoundé 1. 382 p.

Priso Dickens, D. (2016). L'homme avance et la foret recule. Production urbaine en zone périphérique de Douala: Processus, acteurs et enjeux. Yaounde: Edition CLE, 238 p. 
Priso Olivier (2014). The Issue of Implementation of Town Planning Documents in Cameroon: Towards New Dynamism in the Issuance of Town Planning Instruments. 7 p.

Tchounga, T. G. (2015). Gouvernance Locale et Gestion des Risques Naturels dans L'Arrondissement de Douala V. Mémoire de Master 2 en Géographie, Université de Douala. 179 p. 